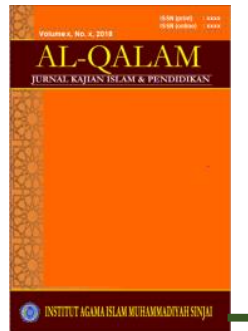

\title{
AL-QALAM
}

Jurnal Kajian Islam \& Pendidikan

Volume 9, No. 1, 2017

ISSN (print) : 1858-4152

ISSN (online) : xxxx-xxxx

Homepage : http://journal.iaimsinjai.ac.id/index.php/al-qalam

\section{STRATEGI PEMBELAJARAN GURU AKIDAH AKHLAK DALAM PEMBINAAN AKHLAK PESERTA DIDIK DI MI AL-ABRAR MAKASSAR}

\author{
Oleh : Syamsir ${ }^{1}$ \\ $* * *$
}

\begin{abstract}
Abstrak
Penelitian ini menggunakan metode pendekatan interdisipliner, yaitu pedagogis, psikologis, teologis, yuridis dan manajemen.Jenis penelitian ini adalah deskripsi kualitatif dengan teknik pengumpulan data dalam bentuk observasi, dokumentasi dan wawancara. Data yang diperoleh kemudian dianalisis secara berkesinambungan dengan cara mereduksi data, display data dan verifikasi data. Setelah melakukan analisis terhadap data yang diperoleh maka hasilnya menunjukkan adanya peningkatan akhlak mulia peserta didik di MI al-Abrar Makassar, yang meliputi sikap kesoponan, kejujuran dan kedisiplinan yang dicapai melalui penerapan strategi pembelajaran dengan berbagai macam metode yaitu keteladanan, pembiasaan, ceramah, tanya jawab, demonstrasi, kerja kelompok dan resitasi/pemberian tugas. Adapun proses penerapan strategi pembelajaran tersebut yang secara umum dilakukan melalui tiga tahap yaitu tahap permulaan (praintruksional), tahap pengajaran (intruksional) dan tahap penilaian tindak lanjut. Berbagai proses penerapan strategi pembelajaran guru akidah akhlak dalam pembinaan akhlak mulia peserta didik di MI al-Abrar Makassar hendaklah dipertahankan, bahkan kalau perlu ditingkatkan dengan berbagai kreativitas yang mampu menunjang proses pembinaan akhlak mulia bagi peserta didik. Selain itu, upaya maksimal yang telah dilakukan guru akidah akhlak dalam pembinaan akhlak mulia peserta didik juga perlu inovasi dengan semakin menggali potensi-potensi sumber daya pendidikan yang ada guna pembinaan yang berkelanjutan. Dukungan seluruh aspek pendidikan hendaklah sejalan dengan program pembinaan yang dilakukan guru akidah akhlak, turutamaketeladanan, pembiasaan dan pengawasan dalam lingkungan keluarga, masyarakat dan sekolah.
\end{abstract}

KATA KUNCI : Strategi, Guru, Akhlak Peserta Didik

\section{PENDAHULUAN}

${ }^{1}$ Dosen Institut Agama Islam (IAI) Muhammadiyah Sinjai 


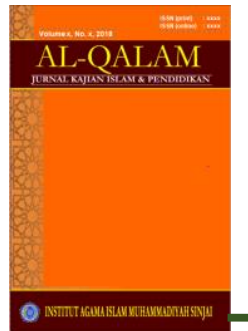

\section{AL-QALAM}

Jurnal Kajian Islam \& Pendidikan

Volume 9, No. 1, 2017

ISSN (print) : 1858-4152

ISSN (online) : xxxx-xxxx

Homepage : http://journal.iaimsinjai.ac.id/index.php/al-qalam

alah satu hal yang sangat urgen untuk diperhatikan dalam rangka pencapaian tujuan pembelajaran adalah strategi pembelajaran. Strategi pembelajaran akanberpengaruh terhadap sikap dan respon peserta didik dalam menerima pelajaran. Kemp dalam WinaSanjaya menjelaskan bahwa strategi pembelajaran adalah suatu kegiatan pembelajaran yang harus dikerjakan guru dan peserta didik agar tujuan pembelajaran dapat tercapai secara efektif dan efesien. $^{2}$

Secara langsung maupun tidak langsung harus diakui bahwa strategi pembelajaran mempunyai peran yang sangat penting dalam dunia pendidikan.Salah satu penyebab kegagalan dalam pentransferan ilmu pengetahuan kepada peserta didik adalah karena strategi pembelajaran yang diterapkan oleh guru di dalam kelas tidak tepat dan tidak variatif.Karenanya inovasi dan kreativitas guru dalam menggunakan strategi pembelajaran menjadi hal yang mutlak diperhatikan.

Sehubungan dengan hal itu, Undang-Undang RI Nomor 20 Tahun 2003 tentang Sistem Pendidikan Nasional Pasal 3 menyatakan bahwa:

Pendidikan nasional berfungsi mengembangkan kemampuan dan membentuk watak serta peradaban bangsa yang bermartabat dalam rangka mencerdaskan kehidupan bangsa, bertujuan untuk mengembangkan potensi peserta didik agar menjadi manusia yang beriman dan bertakwa kepada Tuhan Yang Maha Esa, berakhlak mulia, cakap, kreatif, mandiri, menjadi warga negara yang demokratis, dan bertanggungjawab. ${ }^{3}$

Sejalan dengan tujuan tersebut dalam Peraturan Menteri Agama RI Nomor 16 Tahun 2010 tentang pengelolaan pendidikan agama pada sekolah, Bab 1 Pasal 1, dijelaskan bahwa pendidikan agama adalah pendidikan yang memberikan pengetahuan dan membentuk sikap, kepribadian dan keterampilan peserta didik

${ }^{2}$ WinaSanjaya, Strategi Pembelajaran Berorentasi Standar Proses Pendidikan (Cet. VII; Jakarta: Kencana, 2010), h. 126.

${ }^{3}$ Republik Indonesia, Undang-Undang RI Nomor 20 Tahun 2003 tentang Sistem Pendidikan Nasional (Cet. IV; Jakarta: Sinar Grafika, 2014), h. 7.

Al-Qalam Volume 9 Nomor: 1, 2017

Page | 124 


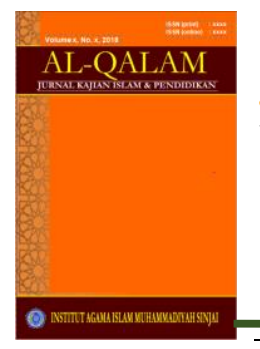

\section{AL-QALAM}

Jurnal Kajian Islam \& Pendidikan

Volume 9, No. 1, 2017

ISSN (print) : 1858-4152

ISSN (online) : $\mathrm{xxxx}-\mathrm{xxxx}$

Homepage : http://journal.iaimsinjai.ac.id/index.php/al-qalam

dalam mengamalkan ajaran agamanya, yang dilaksanakan sekurang-kurangnya melalui mata pelajaran pada semua jalur, jenjang dan jenis pendidikan. ${ }^{4}$

Ketentuan tersebut di atas menempatkan pendidikan agama pada posisi yang amat strategis dalam upaya mencapai tujuan pendidikan yang tidak lepas dari tujuan pendidikan Islam.

Dalam keseluruhan ajaran Islam, akhlak menempati kedudukan yang istimewa dan sangat penting, sehingga Islam menjadikan akhlak sebagai bukti dan buah dari ibadah kepada Allah swt. ${ }^{5}$

Akhlak merupakan bagian yang tidak dapat dipisahkan dalam kehidupan umat manusia, terutama dalam kehidupan anak atau peserta didik.Akhlak adalah mutiara hidup yang membedakan makhluk manusia dan makhluk hewani. Manusia tanpa akhlak akan hilang derajat kemanusiaannya sebagai makhluk Allah yang paling mulia. Demikian pentingnya akhlak dalam segala aspek kehidupan manusia sehingga Allah swt.memerintahkan sebagaimana firman-Nya dalam Q.S. Ali Imran/3: 104.

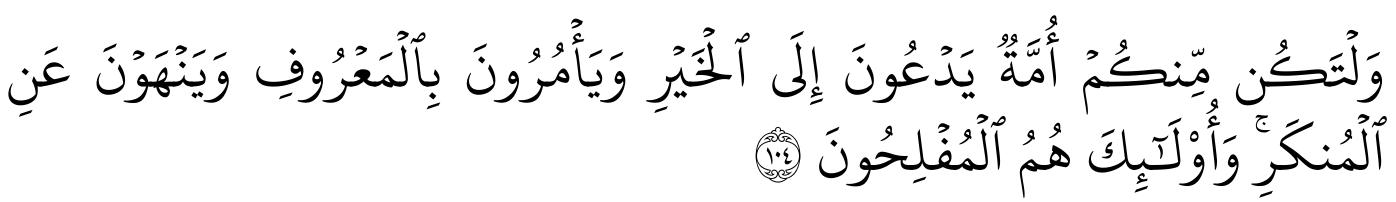

Terjemahnya:

Dan hendaklah ada diantara kamu ada segolongan orang yang menyeru kepada kebajikan, menyuruh berbuat yang ma'ruf dan mencegah dari yang munkar dan mereka itulah orang-orang yang beruntung. ${ }^{6}$

${ }^{4}$ Kementerian Agama RI,Peraturan Menteri Agama Nomor 16 Tahun 2010 Tentang Penge-lolaan Pada Sekolah (Jakarta: Direktorat Jendral Pendidikan Islam, 2011), h. 50.

${ }^{5}$ YunaharIlyas, Kuliah Akhlaq (Cet. XI; Yogyakarta: LPPI UMY, 2009), h. 6.

${ }^{6}$ Departemen Agama RI., al-Qur'a>n dan Terjemahnya (Surakarta:MediaInsani Publishing,2007), h. 63. 


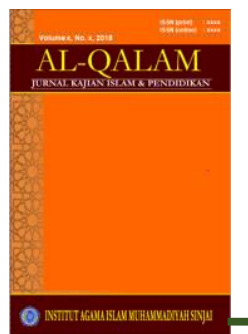

\section{AL-QALAM}

Jurnal Kajian Islam \& Pendidikan

Volume 9, No. 1, 2017

ISSN (print) : 1858-4152

ISSN (online) : xxxx-xxxx

Homepage : http://journal.iaimsinjai.ac.id/index.php/al-qalam

Ayat tersebut menunjukkan bahwa betapa pentingnya akhlak sehingga Allah swt.memberi keberuntungan kepada umat manusia di muka bumi ini karena kebaikan yang mereka miliki.

Agama yang sangat menjunjung tinggi akhlak adalah agama Islam. Dalam salah satu keterangan hadis dinyatakan dengan tegas bahwa tujuan utama Rasulullah saw. diutus ke permukaan bumi adalah untuk menyempurnakan akhlak mulia. Hal ini sesuai dengan sabda Rasulullah saw.

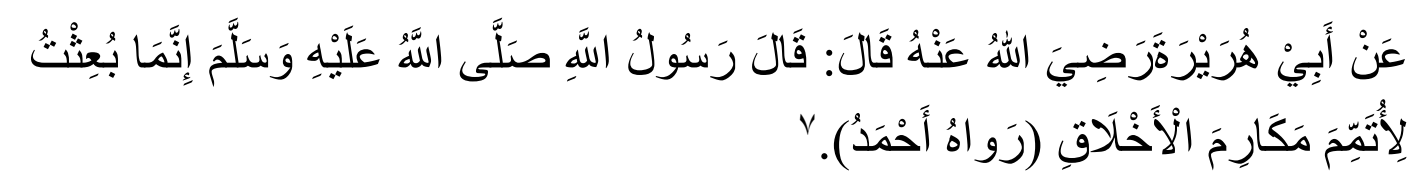

Artinya:

"Dari Abu Hurairahra.berkata, Rasulullah saw. bersabda: Sesungguhnya aku diutus untuk menyempurnakan akhlak mulia". (H.R. Ahmad).

Hadis di atas memberikan pemahaman bahwa akhlak merupakan sebuah misi kerasulan yang sangat suci dan abadi.Dalam hal ini bukan hanya akhlak kepada Allah swt.yang diharapkan Islam atas umatnya, namun akhlak yang diajarkan Islam juga menyangkut kehidupan sosial dengan sesama, bahkan semua makhluk hidup.

Dalam kehidupan sosial kemanusiaan, pendidikan bukan hanya suatu upaya yang melahirkan pembelajaran yang bermaksud membawa manusia menjadi sosok yang potensial secara intelektual. Akan tetapi proses tersebut juga bernuansa pada upaya pembentukan masyarakat yang berwatak, berakhlak, beretika dan berestetika.

Menghadapi perkembangan zaman yang setiap waktu mengalami perubahan maka perhatian terhadap pembinaan akhlak peserta didik semakin

\footnotetext{
${ }^{7}$ Ahmad bin Muhammad IbnuHanbal, al-Musnad al-Imam Ahmad (Jilid II; Cairo: 2004), h.7.
} 


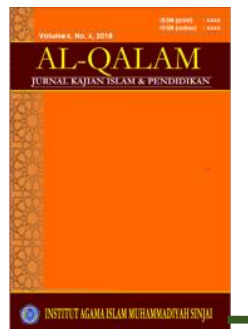

\section{AL-QALAM}

Jurnal Kajian Islam \& Pendidikan

Volume 9, No. 1, 2017

ISSN (print) : 1858-4152

ISSN (online) : xxxx-xxxx

Homepage : http://journal.iaimsinjai.ac.id/index.php/al-qalam

mendesak untuk dilakukan, melihat nilai-nilai moral yang dimiliki peserta didik sekarang ini semakin berkurang dan sangat memprihatinkan,baik peserta didik yang berasal dari lingkungan sekolah umum maupun yang berasal dari lingkungan sekolah agama/madrasah. Fenomena tersebut ternyata juga terjadi di MI al-Abrar Makassar.

Adapun fakta empiris yang ditemukan ketika peneliti melakukan observasi awal yaitu (1) masih ditemukan peserta didik yang memiliki perilaku yang tidak sopan atau tidak saling menghormati; (2) tidak jujur; (3) tidak disiplin; (5) guru yang tidak profesional dalam menjalankan tugasnya sebagai pendidik, seperti menerapkan strategi pembelajaran yang tidak tepat atau monoton.

\section{METODE PENELITIAN}

Penelitian ini menggunakan metode pendekatan interdisipliner, yaitu pedagogis, psikologis, teologis, yuridis dan manajemen. Jenis penelitian ini adalah deskripsi kualitatif dengan teknik pengumpulan data dalam bentuk observasi, dokumentasi dan wawancara. Data yang diperoleh kemudian dianalisis secara berkesinambungan dengan cara mereduksi data, display data dan verifikasi data.

\section{PEMBAHASAN}

\section{A. Pengertian Strategi}

Awalnya istilah strategi digunakan dalam dunia militer dan diartikan sebagai cara penggunaan seluruh kekuatan militer untuk memenangkan suatu peperangan. Seorang yang berperang dalam mengatur strategi, untuk memenangkan peperangan sebelum melakukan suatu tindakan, ia akan menimbang bagaimana kekuatan pasukan yang dimilkinya baik dilihat dari kuantitas maupun kualitasnya. Setelah semuanya diketahui, kemudian ia 


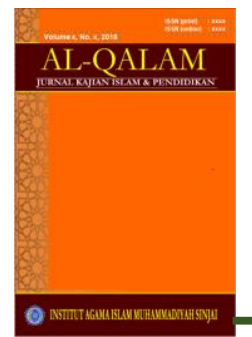

\section{AL-QALAM}

Jurnal Kajian Islam \& Pendidikan

Volume 9, No. 1, 2017

ISSN (print) : 1858-4152

ISSN (online) : xxxx-xxxx

Homepage : http://journal.iaimsinjai.ac.id/index.php/al-qalam

menyusus tindakan yang harus dilakukan, baik taktik dan teknik peperangan maupun waktu yang tepat untuk melakukan suatu serangan. ${ }^{8}$

Dalam Kamus Umum Bahasa Indonesia, strategi diartikan sebagai akal (tipu muslihat) untuk mencapai maksud. Sedangkan strategi dalam Bahasa Inggris disebut strategy yang berarti akal atau siasat. ${ }^{9}$ Secara umum strategi mempunyai pengertian suatu garis-garis besar haluan untuk bertindak dalam usaha mencapai sasaran yang telah ditentukan. ${ }^{10}$

J. R. David dalam Wina Sanjaya mengemukakan bahwa: strategi diartikan sebagai a plan, method, or series of activities designed to achieves a particular educational goal. ${ }^{11}$ Artinya adalah suatu rencana, metode atau rangkaian kegiatan yang didesain untuk mencapai tujuan pendidikan. Strategi merupakan "a plan of operation achieving something". ${ }^{12}$ Artinya bahwa strategi adalah suatu rencana yang dilakukan untuk mencapai suatu tujuan (kesuksesan).

Apabila antara strategi, metode, teknik dan taktik pembelajaran sudah terangkai menjadi satu kesatuan yang utuh maka terbentuklah apa yang disebut dengan model pembelajaran. Jadi model pembelajaran pada dasarnya merupakan bentuk pembelajaran yang tergambar dari awal sampai akhir yang disajikan secara khas oleh guru. ${ }^{13}$

Dalam kegiatan pembelajaran, posisi hierarkis dari masing-masing istilah tersebut dapat divisualisaikan sebagai berikut:

${ }^{8}$ Iif Khairu Ahmadi dkk., op. cit., h. 10.

${ }^{9}$ John M. Echols dan Hassan Shadily, Kamus Inggris Indonesia (Cet. XXVI; Jakarta: Gramedia, 2005), h. 560.

${ }^{10}$ Abuddin Nata, Perspektif Islam tentang Strategi Pembelajaran (Cet. II; Jakarta: Kencana, 2011), h. 206.

${ }^{11}$ Wina Sanjaya, Kurikulum dan Pembelajaran: Teori dan Praktik KTSP (Cet. III; Jakarta: Prenada Media Group, 2010), h. 299.

${ }^{12}$ Kokom Komalasari, op. cit., h. 56.

${ }^{13}$ Ibid., h. 57. 


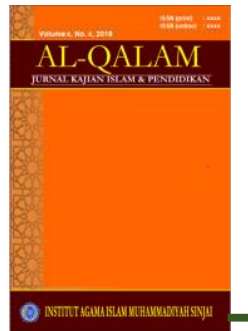

\section{AL-QALAM}

Jurnal Kajian Islam \& Pendidikan

Volume 9, No. 1, 2017

ISSN (print) : 1858-4152

ISSN (online) : xxxx-xxxx

Homepage : http://journal.iaimsinjai.ac.id/index.php/al-qalam

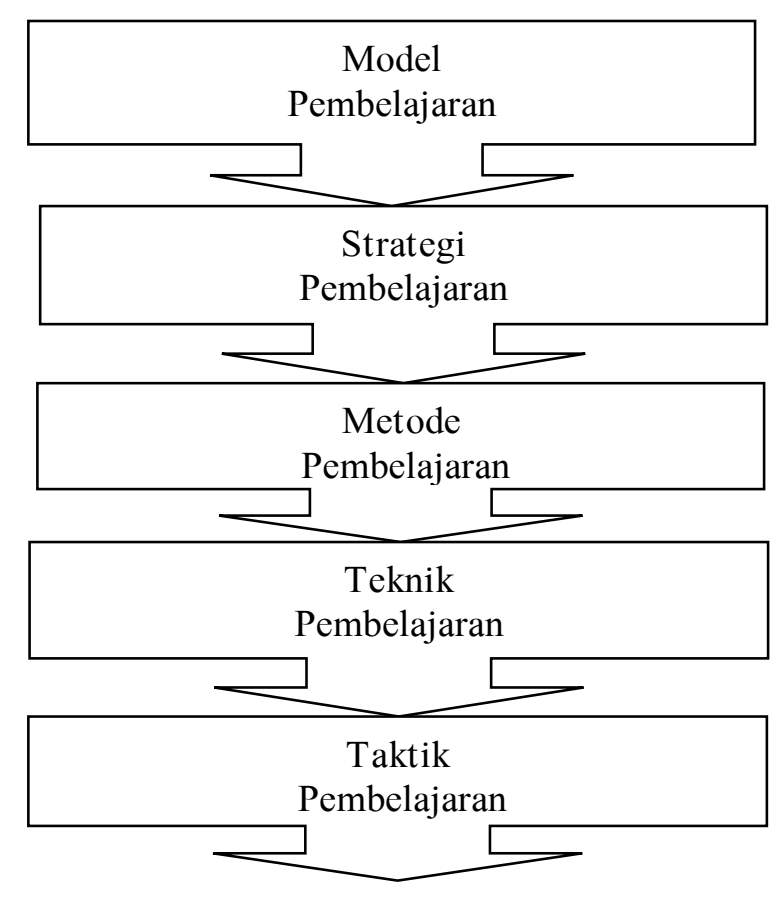

Bertolak dari beberapa definisi di atas maka penulis mengambil suatu konklusi bahwa istilah strategi, metode, teknik dan taktik apabila ditinaju dari segi tujuannya maka pada prinsipnya sama yaitu suatu cara yang dilakukan untuk mencapai suatu tujuan tertentu. Namun apabila ditinjau dari segi implementasinya, istilah-istilah tersebut memiliki perbedaan.

\section{Kriteria Pemilihan Strategi Pembelajaran}

Pemilihan strategi pembelajaran yang akan digunakan dalam pembelajaran harus beroientasi pada tujuan pembelajaran yang akan dicapai. Selain itu, juga harus disesuaikan dengan jenis materi, karakteristik peserta didik serta situasi atau kondisi dimana pembelajaran tersebut akan berlangsung. Terdapat beberapa metode yang dapat digunakan oleh guru, tetapi tidak semuanya sama efektifnya 


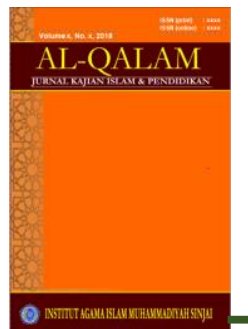

\section{AL-QALAM}

Jurnal Kajian Islam \& Pendidikan

Volume 9, No. 1, 2017

ISSN (print) : 1858-4152

ISSN (online) : xxxx-xxxx

Homepage : http://journal.iaimsinjai.ac.id/index.php/al-qalam

dapat mencapai tujuan pembelajaran. Untuk itu dibutuhkan kreativitas guru dalam memilih strategi pembelajaran tersebut. ${ }^{14}$

Pemilihan strategi pembelajaran hendaknya ditentukan berdasarkan kriteria berikut:

a. Orientasi strategi pada tugas pembelajaran

b. Relevan dengan isi

c. Metode dan teknik yang digunakan difokuskan pada tujuan yang ingin dicapai

d. Media pembelajarn yang digunakan dapat merangsang indra peserta didik secara simultan.

2. Komponen Strategi Pembelajaran

Pembelajaran merupakan suatu sistem intruksional yang mengacu pada seperangkat komponen yang saling bergantung satu sama lain untuk mencapai tujuan. Selaku suatu sistem, pembelajaran meliputi suatu komponen, antara lain tujuan, bahan, peserta didik, guru, metode, situasi dan evaluasi. Agar tujuan itu tercapai, semua komponen yang ada harus diorganisasikan sehinggan antar sesama komponen terjadi kerja sama. ${ }^{15}$

a. Tujuan Pembelajaran

Tujuan pembelajaran merupakan dasar yang dijadikan landasan untuk menetukan strategi, materi, media dan evaluasi pembelajaran. Untuk itu, dalam strategi pembelajaran, penentuan tujuan pembelajaran merupakan komponen yang pertama kali harus dipilih oleh seorang guru.

b. Bahan Pelajaran

Bahan pelajaran merupakan medium untuk mencapai tujuan pembelajaran yang berupa materi yang tersusun secara sistematis dan dinamis sesuai dengan

${ }^{14}$ Hamzah B. Uno, Model Pembelajaran Menciptakan Proses Belajar-Mengajar yang Kreatif dan Efektif (Cet. VI; Jakarta: Bumi Aksara, 2010), h. 7.

${ }^{15}$ Iif Khairu Ahmadi dkk., op. cit., h. 19. 


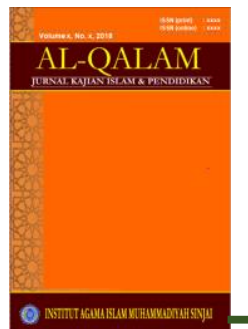

\section{AL-QALAM}

Jurnal Kajian Islam \& Pendidikan

Volume 9, No. 1, 2017

ISSN (print) : 1858-4152

ISSN (online) : xxxx-xxxx

Homepage : http://journal.iaimsinjai.ac.id/index.php/al-qalam

arah tujuan dan perkembangan kemajuan ilmu pengetahuan dan tuntutan masyarakat.

c. Peserta Didik

Peserta didik merupakan komponen yang melakukan kegiatan belajar untuk mengembangkan potensi kemampuan menjadi nyata untuk mencapai tujuan pembelajaran .

d. Guru

Guru adalah pelaku pembelajaran, sehingga dalam hal ini guru merupakan faktor yang terpenting yang dapat memanipulasi komponen strategi pembelajaran lainnya. lain.

e. Metode

Metode adalah suatu cara yang dipergunakan untuk mencapai tujuan pembelajaran yang telah ditetapkan. Penentuan metode yang akan digunakan guru dalam kegiatan pembelajaran sangat menentukan berhasil tidaknya pembelajaran yang berlangsung.

\section{f. Situasi}

Situasi sangat mempengaruhi guru dalam menentukan strategi pembelajaran. Situasi yang dimaksud adalah keadaan lingkungan di sekolah atau di madrasah tersebut.

g. Evaluasi

Secara mendasar, evaluasi bersifat selaras, serasi dan koheren dengan kompetensi/tujuan pembelajaran, hasil pembelajaran, materi pembelajaran dan strategi pembelajaran. ${ }^{16}$ Evaluasi merupakan komponen strategi yang berfungsi 100.

\footnotetext{
${ }^{16}$ Bermawy Munthe, Desain Pembelajaran (Cet. V; Yogyakarta: Insan Madani, 2011), h.
} 


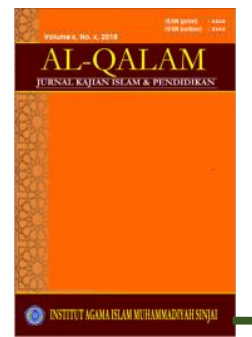

\section{AL-QALAM}

Jurnal Kajian Islam \& Pendidikan

Volume 9, No. 1, 2017

ISSN (print) : 1858-4152

ISSN (online) : xxxx-xxxx

Homepage : http://journal.iaimsinjai.ac.id/index.php/al-qalam

untuk mengetahui apakah tujuan yang telah ditetapkan telah tercapai atau belum, juga sebagai umpan balik untuk perbaikan strategi yang telah ditetapkan. ${ }^{17}$

\section{B. Hasil Penelitian}

1. Proses penerapan strategi pembelajaran guru akidah akhlak dalam pembinaan akhlak mulia peserta didik didik di MI al-Abrar Makassar

Setelah penulis melakukan penelitian maka ditemukan hasil penelitian bahwa proses penerapan strategi pembelajaran guru akidah akhlak dalam pembinaan akhlak mulia peserta didik didik di MI al-Abrar Makassar, dapat ditunjukkan dengan melalui beberapa tahap yaitu tahap permulaan (praintruksional), tahap pengajaran (intruksional) dan tahap penilaian dan tindak lanjut. Bentuk strategi pembelajaran guruakidah akhlak dalam pembinaan akhlak mulia peserta didik di MI al-Abrar Makassar, yaitu dilakukan dalam bentuk program harian, mingguan, bulanan dan program tahunan.Dari setiap program tersebut memiliki kegiatan yang berbeda-beda. Misalnya:

a. Program Harian

Dalam program ini, isinya memuat tentang anjuran peserta didik dan guru untuk melaksanakan salatberjamaahzuhur bagi yang masuk pagi dan salatberjamaahazar bagi yang masuk siang serta datang dan pulang tepat waktu. Kegiatan ini dimaksudkan untuk menanamkan sikap kedisiplinan terhadap peserta didik dengan melalui metode pembiasaan dan metode keteladanan. Sebagaimana halnya dengan guru yang memberikan keteladanan tentang sikap kedisiplinan dalam melaksanakan tugas dan salatberjamaah, peserta didik juga dibiasakan melakukan hal yang serupa.

Teknik pelaksanaannya sebagaimana dijelaskan Rustan bahwa ketika masuk waktu zuhur dan azar diberi dispensasi untuk melaksanakan salatzuhur dan

${ }^{17}$ Iif Khairu Ahmadu dkk.,op. cit., ., h. 20. 


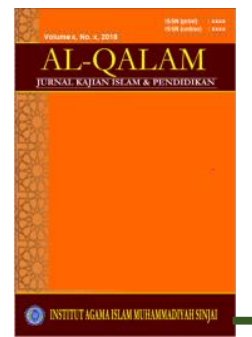

\section{AL-QALAM}

Jurnal Kajian Islam \& Pendidikan

Volume 9, No. 1, 2017

ISSN (print) : 1858-4152

ISSN (online) : xxxx-xxxx

Homepage : http://journal.iaimsinjai.ac.id/index.php/al-qalam

asar di masjid.Pelaksanaan kegiatan ini dikoordinir langsung oleh masing-masing wali kelasnya.Apabila wali kelasnya berhalangan maka dipercayakan oleh ketua kelasnya.Tujuan kegiatan ini adalah untuk melatih peserta didik terbiasa dalam melaksanakan shalat berjamaah secara rutin. ${ }^{18}$

b. Program Mingguan

Program mingguan ini, diistilakan dengan kegiatan Jumat ibadah. Berdasarkan hasil wawancara dari Fujiah, dia mengungkapkan bahwa inti dari kegiatan ini adalah menanamkan sikap kedisiplinan dan kesopanan peserta didik melalui metode keteladanan, pembiasaan, ceramah, tanya jawab, demonstrasi dan resitasi atau pemberian tugas. ${ }^{19}$

Dalam kegiatan ini, setiap hari Jumat semua peserta didik yang masuk pagi diharuskan memakai pakaian muslim dan datang di sekolah paling lambat satu jam sebelum masuk waktu jam pelajaran di dalam kelas, begitu pula dengan guru akidah akhlak yang diberi tugas atau amanah untuk membina peserta didik dalam melaksanakan kegiatan Jumat ibadah, diharuskan datang lebih awal. Ini dimaksudkan agar sebelum peserta didik masuk belajar di dalam kelas, terlebih dahulu melaksanakan berbagai macam bentuk kegiatan ibadah atau kegiatan yang terkait dengan pembinaan akhlak mulia. Adapun kegiatan tersebut yaitu:Melaksanakan praktik adzan; Praktik salatfardu secara berjamaah; Zikir bersama setelah salat; Berdoa;Bersedekah melalui kotak amal yang diedarkan oleh peserta didik;Menghafal surah-surah pendek, ayat-ayat pilihan dan doa-doa harian; Mendengarkann ceramah atau kultum, baik yang disampaikan oleh guru maupun yang disampaikan oleh peserta didik itu sendiri.

c. Program Bulanan

\footnotetext{
${ }^{18}$ Rustan,Guru Akidah Akhlak, Wawancara,Makassar, tanggal 15 Februari 2012.

${ }^{19}$ Fujiah,Guru Akidah Akhlak, Wawancara, Makassar, tanggal 14 Februari 2012.
} 


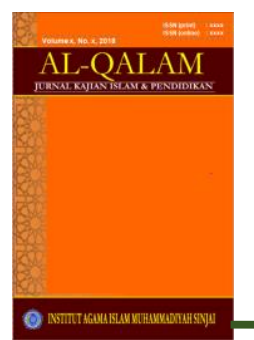

\section{AL-QALAM}

Jurnal Kajian Islam \& Pendidikan

Volume 9, No. 1, 2017

ISSN (print) : 1858-4152

ISSN (online) : xxxx-xxxx

Homepage : http://journal.iaimsinjai.ac.id/index.php/al-qalam

Dalam program ini, setiap bulan guru mengadakan meeting atau petemuan dengan tujuan untuk berbagi pengalaman tentang bagaimana metode mengajar yang efektif dan efisien khususnya dalam pembinaan akhlak mulia peserta didik. Dalam pertemuan ini dihadiri oleh ibu kepala Madrasah untuk melihat apa kendala-kendala yang dialami oleh guru akidah akhlak dalam pembinaan akhlak mulia peserta didik.Hal ini ini diungkap oleh Marina. ${ }^{20}$

d. Program Tahunan

Program tahunan ini.Dilaksanakan dalam bentuk kegiatan buka puasa bersama dan kegiatan pesantren kilat.Kegiatan ini diprogramkan sekali setahun pada bulan suci Ramadhan dengan penanggung jawab semua guru yang ada di MI al-Abrar Makassar ditambah dengan kepala Madrasah dan orang tua peserta didik yang bertempat tinggal di sekitar madrasah tersebut.Teknik pelaksanaannya, guru membentuk panitia khusus yang diberi tugas masing-masing untuk dilaksanakan dan dipertanggungjawabkan.Untuk buka puasanya diundang seluruh warga sekolah, warga masyarakat yang bertempat tinggal di sekitar madrasah dan seluruh orang tua peserta didik.Tujuan kegiatan ini, disamping untuk melakukan dan memperbaiki silaturrahim antara guru orang tua peserta didik dan warga masyarakat juga untuk pembinaan roahani dan sikap kedisiplinan serta kejujuran dalam melaksanakan ibadah puasa yang diberikan oleh ustadz yang membawakan ceramah sebelum berbuka puasa.Setelah itu, sekitar tujuh menit sebelum buka puasa ceramahnya dilanjutkan oleh guru akidah akhlak yang isinya mengenai pentingnya sikap jujur dalam berpuasa. Di sini guru menggunakan metode ceramah dan tanya jawab bersama dengan peserta didik. Hal ini diungkap oleh Arman guru akidah akhlak. ${ }^{21}$

\footnotetext{
${ }^{20}$ Marina, Guru Akidah Akhlak, Wawancara,Makassar, tanggal 14 Februari 2012.

${ }^{21}$ Arman,Guru Akidah Akhlak, Wawancara, Makassar, tanggal 15 Februari 2012.
} 


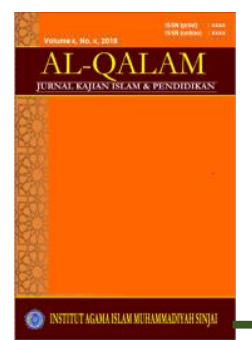

\section{AL-QALAM}

Jurnal Kajian Islam \& Pendidikan

Volume 9, No. 1, 2017

ISSN (print) : 1858-4152

ISSN (online) : xxxx-xxxx

Homepage : http://journal.iaimsinjai.ac.id/index.php/al-qalam

2. Faktor pendukung dan penghambat dalam pembinaan akhlak mulia peserta didik di MI al-Abrar Makassar

Adapun yang menjadi faktor pendukung sebagai awal keberhasilan dalam pembinaan akhlak mulia peserta didik sebagaimana yang dikemukakan oleh A. HarmiahTannang adalah faktor internal dan eksternal.Faktor internal di antaranya adalah faktor pembawaan peserta didik, kualitas dan keprofesionalan yang dimiliki oleh guru akidah akhlak, kurikulum, sarana dan prasarana.Adapun faktor eksternalnya adalah dukungan masyarakat yangbertempat tinggal di sekitar lingkungan Madrasah, keluarga dan peran serta orang tua. ${ }^{22}$

Sedangkan faktor penghambatnyasebagaimana yang dituturkan oleh CatriWidunadalah faktor internal yaitu faktor pembawaan peserta didik, alokasi waktu pembelajaran akidah akhlak yang hanya dua jam pelajaran dalam seminggu sehingga merupakan salah satu penyebab sulitnya mencapai tujuan pembelajaran sebagaimana yang diinginkan. Adapun faktor eksternal yang menjadi penghambat pembinaan akhlak mulia peserta didik di MI al-Abrar Makassar di antaranya adalah faktor lingkungan keluargaseperti minimnya pengawasan orang tua terhadap anaknya,lingkungan masyarakat dan arus globalisasi modern. Solusi faktor penghambat pembinaan akhlak mulia peserta didik di MI al-Abrar Makassar adalah melakukan pelatihan peningkatan mutu guru melalui kualifikasi guru, pelatihan Kelompok Kerja Guru (KKG) dan pelatihan workshop, memberikan layanan pendidikan yang bermutu untuk menghasilkan tamatan yang berakhlak mulia, melakukan kegiatan tambahan yang terkait dengan pembinaan

\footnotetext{
${ }^{22}$ A. HarmiahTannang, Kepala Madrasah, Wawancara, Makassar, tanggal 13 Februari 2012.
} 


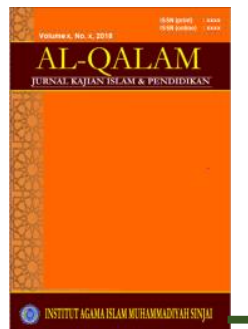

\section{AL-QALAM}

Jurnal Kajian Islam \& Pendidikan

Volume 9, No. 1, 2017

ISSN (print) : 1858-4152

ISSN (online) : xxxx-xxxx

Homepage : http://journal.iaimsinjai.ac.id/index.php/al-qalam

akhlak mulia di luar jam pelajaran sekolah atau yang lebih dikenal dengan kegiatan ekstrakurikuler. ${ }^{23}$

3. Hasil penerapan strategi pembelajaran guru akidah akhlak dalam pembinaan akhlak mulia peserta didik di MI al-Abrar Makassar

Penerapan strategi pembelajaran guru akidah akhlak dalam pembinaan akhlak mulia peserta didik di MI al-Abrar Makassar menunjukkan hasil adanya peningkatan akhlak mulia peserta didik di antaranya adalah sikap kesopanan dalam berbicara sesama guru dan temannya, kejujuran dalam mengerjakan soal ulangan yang diberikan oleh gurunya, dan sikap kedisiplinan dalam mengikuti segala kegiatan dan aturan atau tata tertib yang ada di Madrasah tersebut.

\section{KESIMPULAN}

1. Proses penerapan strategi pembelajaran guru akidah akhlak dalam pembinaan akhlak mulia peserta didik didik di MI al-Abrar Makassar, dapat ditunjukkan dengan melalui beberapa tahap yaitu tahap permulaan (praintruksional), tahap pengajaran (intruksional) dan tahap penilaian dan tindak lanjut.

2. Faktor-faktor yang menjadi pendukung dalam pembinaan akhlak mulia peserta didik di MI al-AbrarMakassar yaitu faktor internal di antaranya adalah faktor pembawaan peserta didik, kualitas dan keprofesionalan yang dimiliki oleh guru akidah akhlak, kurikulum, sarana dan prasarana. Adapun faktor eksternalnya adalah dukungan masyarakat yangbertempat tinggal di sekitar lingkungan Madrasah, keluarga dan peran serta orang tua.Sedangkan faktor penghambatnya adalah faktor internal yaitu faktor pembawaan peserta didik, alokasi waktu pembelajaran.Adapun faktor eksternal yang menjadi penghambat pembinaan akhlak mulia peserta didik di MI al-Abrar Makassar

\footnotetext{
${ }^{23}$ CatriWindun, Wakil Kepala Madrasah, Wawancara,Makassar, tanggal 13 Februari 2012.
}

Al-Qalam Volume 9 Nomor : 1, 2017

Page | 136 


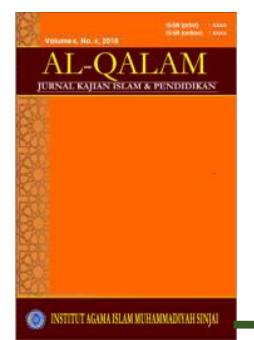

\section{AL-QALAM}

Jurnal Kajian Islam \& Pendidikan

Volume 9, No. 1, 2017

ISSN (print) : 1858-4152

ISSN (online) : xxxx-xxxx

Homepage : http://journal.iaimsinjai.ac.id/index.php/al-qalam

di antaranya adalah faktor lingkungan keluargaseperti minimnya pengawasan orang tua terhadap anaknya,lingkungan masyarakat dan arus globalisasi modern. Solusi faktor penghambatnya adalah melakukan pelatihan peningkatan mutu guru melalui kualifikasi guru, pelatihan KKG dan pelatihan workshop, memberikan layanan pendidikan yang bermutu untuk menghasilkan tamatan yang berakhlak mulia, melakukan kegiatan tambahan yang terkait dengan pembinaan akhlak mulia di luar jam pelajaran sekolah atau yang lebih dikenal dengan kegiatan ekstrakurikuler.

3. Penerapan strategi pembelajaran guru akidah akhlak dalam pembinaan akhlak mulia peserta didik di MI al-Abrar Makassar menunjukkan hasil adanya peningkatan akhlak mulia peserta didik di antaranya adalah sikap kesopanan dalam berbicara sesama guru dan temannya, kejujuran dalam mengerjakan soal ulangan yang diberikan oleh gurunya, dan sikap kedisiplinan dalam mengikuti segala kegiatan dan aturan atau tata tertib yang ada di Madrasah tersebut.

\section{DAFTAR PUSTAKA}

Abuddin Nata, Perspektif Islam tentang Strategi Pembelajaran (Cet. II; Jakarta: Kencana, 2011)

Bermawy Munthe, Desain Pembelajaran (Cet. V; Yogyakarta: Insan Madani, 2011)

Deparetemen Agama RI. Al-Qur'an dan Terjemahnya. Solo: Qomari, 2010.

Hamzah B. Uno, Model Pembelajaran Menciptakan Proses Belajar-Mengajar yang Kreatif dan Efektif (Cet. VI; Jakarta: Bumi Aksara, 2010).

Ibnu Hanbal, Ahmad. al-Musnad Ahmad Ibnu Hanbal. Riyadh: Bait al-Afkaar alDauliyyah, 1419 H/1998 M.

Ilyas, Yunahar. Kuliah Akhlaq.Cet. XI; Yogyakarta: LPPI UMY, 2009. 


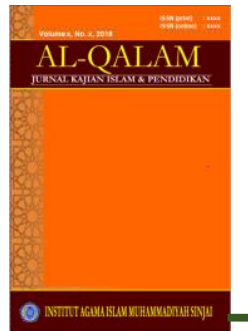

\section{AL-QALAM}

Jurnal Kajian Islam \& Pendidikan

Volume 9, No. 1, 2017

ISSN (print) : 1858-4152

ISSN (online) : xxxx-xxxx

Homepage : http://journal.iaimsinjai.ac.id/index.php/al-qalam

John M. Echols dan Hassan Shadily, Kamus Inggris Indonesia (Cet. XXVI; Jakarta: Gramedia, 2005)

Kementerian Agama RI. Panduan Umum Penyelenggaraan Kegiatan Ekstrakurikuler Pendidikan Agama Islam Sekolah Menengah Atas dan Sekolah Menengah Kejuruan.Jakarta: Direktorat Jenderal Pendidikan Islam, 2011.

Republik Indonesia. Himpunan Undang-Undang Republik Indonesia. Cet. I; Surabaya: Wacana Intelektual, 2009.

Sanjaya, Wina. Strategi Pembelajaran Beorientasi Standar Proses Pendidikan. Cet. VIII; Jakarta: Kencana, 2011.

Wina Sanjaya, Kurikulum dan Pembelajaran: Teori dan Praktik KTSP (Cet. III; Jakarta: Prenada Media Group, 2010)

Wina Sanjaya, Kurikulum dan Pembelajaran: Teori dan Praktik KTSP (Cet. III;

Jakarta: Prenada Media Group, 2010) 